\title{
Not Well Enough to Attend Appointments: Telehealth Versus Health Marginalisation
}

\author{
Maria A PINERO DE PLAZA, Alline BELEIGOLI, Alexandra MUDD, \\ Matthew TIEU, Penelope MCMILLAN, Michael LAWLESS, \\ Rebecca FEO, Mandy ARCHIBALD and Alison KITSON
}

\begin{abstract}
Temporary telehealth initiatives during COVID-19 have been lifechanging for many people in Australia; for the first time Frail, Homebound, and Bedridden Persons (FHBP) equitably received primary healthcare services, like Australians without a disability. However, government changes to telehealth funding mean that since July 2020 telehealth is only available for those who have attended a face-to-face appointment in the last 12 months, thus excluding FHBP. This paper illustrates the reported health exclusion and marginalisation of FHBP. We reviewed the literature and surveyed 164 Australian adults $(27 \%$ homebound people and $73 \%$ affiliated persons) to ascertain their opinions and thoughts on potential strategies to tackle issues associated with FHBP's current circumstances. Results demonstrate that digital technologies and telehealth services are ethical imperatives. Policymakers, clinicians, and health researchers must work with endusers (community-based participation) to create an inclusive healthcare service.
\end{abstract}

Keywords. telehealth, participatory research, homebound, bedridden, frailty, marginalisation, COVID-19

\section{Introduction}

Frail, Homebound and Bedridden Persons (FHBP) live with complex, incapacitating, and debilitating illnesses. In addition to functional issues, FHBP can experience financial hardship and social isolation, which puts them at a higher risk of depression (1). Social isolation refers to a state of having minimal contact with other people. It is commonly associated with loneliness, the feeling of missing connections, affection, and proximity in relationships (2). People living with complex chronic conditions, such as older FHBP, require connections, care, and support to maintain their relationships, social activities, psychological health, and activities linked to self-care, mobility, and domestic life (3). This can be facilitated using digital technologies (DT), such as mobile phones, tablets, and computers, which enable remote healthcare delivery (i.e. telehealth) (4).

Ongoing support and guidance with medications and self-care are necessary for FHBP; helping them is a critical public health concern globally $(5,6)$. An American feasibility study on the use of telehealth for FHBP demonstrated its perceived benefits for homebound people and a reduction in costs associated with their health administration processes and care (5). These findings are important given that many FHBP experience social exclusion, health disparities, and marginalisation from health services because of the Australian healthcare system being devised mostly around physical (i.e., in-person) attendance (7). 
As an emergency response to COVID-19, Australia activated a National Health Plan, which rapidly expanded the use of telehealth technologies. This plan included increased practice incentive payments and benefits to allow doctors, nurses, midwives, and allied health professionals (including mental health) to deliver telehealth services to all Australian citizens (4). The response demonstrated that Australia is capable of rapidly overcoming critical barriers to the expansion of telehealth, including well described regulatory, financial, cultural, technological, and workforce impediments (8). As described by Ms Penelope Macmillan, Chair of ME/CFS South Australia (Myalgic Encephalomyelitis/Chronic Fatigue Syndrome) - a disease turning many Australians into FHBP: "In the past, clinicians only met clients when the person was well enough to attend an appointment. With the introduction of telehealth for GP services, we could meet with them when our symptoms were too severe to allow us to leave home. The understanding of our illness severity and the nature of our impairments was dramatically improved." (9).

However, on 20 July 2020, without consideration of consumer feedback or needs, access to General Practitioner (GP) telehealth services was terminated for people who had not attended a face-to-face appointment in the last 12 months. The rationale behind the GP-telehealth cut was based on concerns about "the rise in low-value pop-up telehealth services" (10). In situations where cuts to services are being considered, decisionmakers must use evidence to determine the risks and benefits of such choices for consumers and consider how these choices might conflict with matters of ethics and values (11).

For socio-technological change and public health policy to be most useful and supportive of the needs of the public, it is necessary to involve consumers in creating and informing such change or policy $(8,11,12)$. These participatory research (PR) strategies are required in the system-level change and knowledge creation process (e.g., co-design), in which consumers are included in offering their perspectives and interpretations concerning studies and resulting policies $(7,8,11,12)$. Therefore, with an emphasis on a PR approach, this paper aims to explore the key strategies to tackle the pressing issues associated with FHBPs' described circumstances. The study has two objectives: 1) Provide evidence to inform decision making, health practice, and health research in this field, and 2) Explore consumer-centric solutions that address the problems of social isolation, marginalisation, and needs of FHBP.

\section{Method}

This paper reports on the first part of a program of research concerning FHBP in Australia: 'Making the invisible visible: Exploring the experiences of frail, homebound and bedridden people'. The study is approved by the Flinders University Social and Behavioural Research Ethics Committee (Project No. 8557). This paper presents a mixed-method, consumer-centric approach (co-designed with one health consumer as a co-researcher at a peer level with the academic investigators and her FHBP peerreference networks). The method involves two steps:

First step: A rapid scoping review with the aims of identifying existing interventions enhanced by technologies that target social isolation reduction for older adults. The search is focused on previous reviews (Pubmed/Medline), and grey literature (Google/Google Scholar). The results were presented narratively and classified according to the main risk factor addressed by each intervention as per the Framework 
for Isolation for adults over 50 of the AARP Foundation (34), published between April 2014 and April 2020.

Second step: Two questions from a larger online survey (Project No. 8557) were selected to explore the needs of FHBP and solutions/actions to the pressing issues they routinely experience (e.g. social isolation and telehealth; the GP-telehealth cut occurred near the end of data collection). The survey was shared via social media as a press release across different universities platforms and consumers advocate groups.

The first question of the survey: "Excluding an accident or temporary illness, are you permanently unable to leave your home?" distinguished homebound people (using the American Medicare classification for homebound persons as those whose absences from home are infrequent, or for periods of relatively short duration, or to receive medical treatment, 13) from their affiliates (e.g. people experiencing similar conditions, people caring for FHBP or people invested in the issues of FHBP). The second question: "Please, check the boxes that you consider important to help you or other Australians who are facing similar problems to yours" involved multiple selection options about issues with healthcare access. This question facilitated problem identification without demanding much writing from respondents. The list of co-designed options (presented in the survey as potential needs or required solutions or actions) is presented in Table 2. Data were collected from 02/07/2020 until 05/07/2020. Basic descriptive statistics and crosstabulation of variables were used to analyse the data.

\section{Results}

Rapid review: our search retrieved five reviews. The content of reviews is synthesised in Table 1, which outlines risk factors for social isolation, the strategy and technology utilised to overcome these risks, and the examples or comments concerning each publication (as per 34). The evidence in Table 1 demonstrates that current practices and knowledge can be effectively operationalised using digital and similar technologies (e.g. wearables, systems mapping, social media and robots) to mitigate and prevent loneliness and social isolation in older adults with complex health issues. Such knowledge can arguably be adapted to support FHBP living in Australia.

Table 1. Examples of technologies used to mitigate and prevent loneliness and social isolation in older adults.

\begin{tabular}{|c|c|c|c|}
\hline Risk factor & Strategy & Technology & Examples/Comments \\
\hline \multirow[t]{4}{*}{ Living alone } & $\begin{array}{l}\text { Informational social support } \\
\text { (Education/empowerment) }\end{array}$ & Telehealth $(14,15)$ & $\begin{array}{l}\text { Videoconference groups } \\
\text { mediated by health } \\
\text { providers focusing on } \\
\text { education about health } \\
\text { issues led to an } \\
\text { improvement in social } \\
\text { isolation. }\end{array}$ \\
\hline & Increasing social network & Telehealth (16) & $\begin{array}{l}\text { Videoconference delivered } \\
\text { by lay providers during } \\
\text { meals. }\end{array}$ \\
\hline & $\begin{array}{l}\text { An increasing sense of } \\
\text { presence/companionship }\end{array}$ & $\begin{array}{l}\text { Embodied } \\
\text { conversational agent } \\
(17) \\
\end{array}$ & Virtual pet therapy \\
\hline & $\begin{array}{l}\text { The increasing frequency of } \\
\text { social contacts }\end{array}$ & An online platform (18) & $\begin{array}{l}\text { A platform that matches } \\
\text { people who want to donate } \\
\text { meals to ones who are }\end{array}$ \\
\hline
\end{tabular}




\begin{tabular}{|c|c|c|c|}
\hline Risk factor & Strategy & Technology & Examples/Comments \\
\hline & & & $\begin{array}{l}\text { searching for } \\
\text { companionship during } \\
\text { meals }\end{array}$ \\
\hline & $\begin{array}{l}\text { Detecting loneliness and } \\
\text { activating family support }\end{array}$ & $\begin{array}{l}\text { Wearable/telemonitoring } \\
\text { (19) }\end{array}$ & $\begin{array}{l}\text { Monitoring of conversations } \\
\text { and word count throughout } \\
\text { the day then prompting } \\
\text { social contact when levels } \\
\text { drop too low. }\end{array}$ \\
\hline \multirow[t]{9}{*}{$\begin{array}{l}\text { Small social } \\
\text { network } \\
\text { and/or } \\
\text { inadequate } \\
\text { social } \\
\text { support }\end{array}$} & $\begin{array}{l}\text { Promoting integration within } \\
\text { local communities }\end{array}$ & $\begin{array}{l}\text { Online } \\
\text { platforms/websites }(20, \\
21,22)\end{array}$ & $\begin{array}{l}\text { Information-based } \\
\text { intervention that provides } \\
\text { personalised information } \\
\text { and referral service to } \\
\text { increase older adults' } \\
\text { awareness and knowledge } \\
\text { of the services and activities } \\
\text { available to them. }\end{array}$ \\
\hline & & & $\begin{array}{l}\text { Advice on community } \\
\text { events. Focused on older } \\
\text { adults. }\end{array}$ \\
\hline & & & $\begin{array}{l}\text { Focused on culturally and } \\
\text { linguistically diverse people }\end{array}$ \\
\hline & $\begin{array}{l}\text { Promoting integration within } \\
\text { local communities }\end{array}$ & $\begin{array}{l}\text { Geographic information } \\
\text { system mapping (23) }\end{array}$ & $\begin{array}{l}\text { Simple map to find } \\
\text { community organisations. } \\
\text { Focused on older adults }\end{array}$ \\
\hline & $\begin{array}{l}\text { Promoting integration within } \\
\text { local communities }\end{array}$ & Telephone-based (24) & $\begin{array}{l}\text { A resource that provides } \\
\text { older men with } \\
\text { opportunities for mateship, } \\
\text { and the chance to re-connect } \\
\text { with the community }\end{array}$ \\
\hline & $\begin{array}{l}\text { Facilitating integration } \\
\text { within families }\end{array}$ & $\begin{array}{l}\text { Home telehealth and } \\
\text { telemonitoring } \\
\text { combined with social } \\
\text { media (25) }\end{array}$ & $\begin{array}{l}\text { Home telehealth system } \\
\text { from the provision of health } \\
\text { care to enhancing older } \\
\text { adults' interpersonal } \\
\text { communication and social } \\
\text { participation }\end{array}$ \\
\hline & Peer support & $\begin{array}{l}\text { Online social } \\
\text { network/social media } \\
(26)\end{array}$ & $\begin{array}{l}\text { Social media moderated by } \\
\text { health professionals }\end{array}$ \\
\hline & $\begin{array}{l}\text { Promoting structured social } \\
\text { support (social network with } \\
\text { volunteers rather than } \\
\text { acquaintances/friends) }\end{array}$ & Telehealth (27) & $\begin{array}{l}\text { Health provider train } \\
\text { volunteers for conversation } \\
\text { facilitation. Once trained } \\
\text { volunteers facilitate group } \\
\text { discussion utilising } \\
\text { teleconferencing. }\end{array}$ \\
\hline & $\begin{array}{l}\text { Increase opportunities for } \\
\text { social contact }\end{array}$ & Digital games (28) & $\begin{array}{l}\text { Opportunities for meeting } \\
\text { friends online through } \\
\text { games communities for } \\
\text { older adults }\end{array}$ \\
\hline $\begin{array}{l}\text { Major life } \\
\text { transitions }\end{array}$ & Emotional support & $\begin{array}{l}\text { Telehealth/telephone- } \\
\text { based (29) }\end{array}$ & $\begin{array}{l}\text { Online/telephone advice on } \\
\text { how to cope positively with } \\
\text { life after loss. }\end{array}$ \\
\hline \multirow[t]{2}{*}{$\begin{array}{l}\text { Mobility or } \\
\text { sensory } \\
\text { impairment }\end{array}$} & $\begin{array}{l}\text { Increase sense of } \\
\text { presence/companionship }\end{array}$ & $\begin{array}{l}\text { Embodied } \\
\text { conversational } \\
\text { agents/avatars (30) }\end{array}$ & $\begin{array}{l}\text { Full-bodied gesture-based } \\
\text { interactions and avatars can } \\
\text { be used to create a sense of } \\
\text { virtual presence between } \\
\text { older people who are unable } \\
\text { to meet face-to-face. }\end{array}$ \\
\hline & $\begin{array}{l}\text { Increase sense of social } \\
\text { participation }\end{array}$ & $\begin{array}{l}\text { Virtual and augmented } \\
\text { reality (31) }\end{array}$ & $\begin{array}{l}\text { Overcoming social } \\
\text { isolation through the power }\end{array}$ \\
\hline
\end{tabular}




\begin{tabular}{llll}
\hline Risk factor & Strategy & Technology & Examples/Comments \\
\hline & & & $\begin{array}{l}\text { of virtual reality and shared } \\
\text { experiences. Focused on } \\
\text { older adults. }\end{array}$ \\
\hline $\begin{array}{l}\text { Mental } \\
\text { health } \\
\text { condition }\end{array}$ & Peer support & $\begin{array}{l}\text { Online chat forum/social } \\
\text { media (32) }\end{array}$ & $\begin{array}{l}\text { Focused on people with } \\
\text { alcohol and drugs addiction }\end{array}$ \\
\hline $\begin{array}{l}\text { Cognitive } \\
\text { impairment }\end{array}$ & $\begin{array}{l}\text { Facilitate communication } \\
\text { with carers }\end{array}$ & Telepresence robots (33) & $\begin{array}{l}\text { Focused on people with } \\
\text { dementia }\end{array}$ \\
\hline
\end{tabular}

Survey: According to the responses from 164 Australians adults, 27\% of whom are homebound and $73 \%$ representing their affiliates, the five most important needs/actions to help them or other Australians who are facing similar problems are:

- Education for all health professionals and service providers about people with their needs $(96 \%)$

- Educating Centrelink, NDIS, and government services about paperwork difficulties (e.g. providing more time or accepting GP reports rather than specialist paperwork only) (93\%)

- Access to community care services (e.g. NDIS, Aged Care packages) (93\%)

- Adequate Medicare rebates for home visits (93\%)

- Extending the existing telephone or online consults (Telehealth) for rural and remote patients to also cover patients who are housebound or bedbound $(93 \%)$.

The responses from FHBP affiliates were consistent with the importance rankings of homebound respondents. The relevancy of the needs/action list was validated, with most options checked by homebound adults and their affiliates in high percentages (above 64\%).

Table 2. Important actions to help FHBP according to homebound/affiliates.

\begin{tabular}{|c|c|c|c|}
\hline $\begin{array}{l}\text { Important actions (needs) to help you or other Australians who } \\
\text { are facing similar problems to yours }\end{array}$ & Homebound & Affiliates & Total \\
\hline $\begin{array}{l}\text { Education for all health professionals and service providers about } \\
\text { people with your needs }\end{array}$ & 43 & 89 & 132 \\
\hline $\begin{array}{l}\text { Educating Centrelink, NDIS, and government services about } \\
\text { paperwork difficulties, e.g. providing more time or accepting GP } \\
\text { reports rather than specialist paperwork only }\end{array}$ & 42 & 86 & 128 \\
\hline $\begin{array}{l}\text { Access to community care services, for example, NDIS, Aged } \\
\text { Care packages }\end{array}$ & 42 & 82 & 124 \\
\hline Adequate Medicare rebates for home visits & 42 & 81 & 123 \\
\hline $\begin{array}{l}\text { Extending the existing telephone or online consults (Telehealth) } \\
\text { for rural and remote patients to also cover patients who are } \\
\text { housebound or bedbound }\end{array}$ & 42 & 79 & 121 \\
\hline Telephone consults & 40 & 72 & 112 \\
\hline $\begin{array}{l}\text { Ability to fund the testing and medical reports required to access } \\
\text { benefits }\end{array}$ & 39 & 80 & 119 \\
\hline Regular home access to a general practitioner & 39 & 71 & 110 \\
\hline $\begin{array}{l}\text { Access to advocacy services (including legal) to assist with the } \\
\text { day to day issues (e.g. NDIS access, DSP access, discrimination, } \\
\text { access to insurance policies, domestic violence, etc.) }\end{array}$ & 37 & 80 & 117 \\
\hline Home access to psychology (or psychological) services & 37 & 72 & 109 \\
\hline $\begin{array}{l}\text { Find out about how many Australians are living with similar } \\
\text { problems to yours to generate faster solutions }\end{array}$ & 37 & 67 & 104 \\
\hline Services to enable you to keep living in the community & 35 & 75 & 110 \\
\hline Access to housing or accommodation arrangements & 35 & 53 & 88 \\
\hline Access to food services (e.g. Meals on Wheels) & 33 & 66 & 99 \\
\hline
\end{tabular}




\begin{tabular}{lccc}
\hline $\begin{array}{l}\text { Important actions (needs) to help you or other Australians who } \\
\text { are facing similar problems to yours }\end{array}$ & Homebound & Affiliates & Total \\
$\begin{array}{l}\text { Access to services that are equivalent to the help provided by } \\
\text { home palliative care services, for example, regular home visits by }\end{array}$ & 32 & 63 & 95 \\
a nurse or GP & & & \\
Streamlining easier access to patient transport & 29 & 53 & 82 \\
Other & 12 & 27 & 39 \\
\hline Total Count & 45 & 119 & 164 \\
\hline
\end{tabular}

\section{Discussion and Conclusion}

Our rapid review found sufficient evidence to support the use of effective technological, social and health interventions to mitigate some of the negative experiences of FHBP (i.e. concerning health, technology, social isolation, and loneliness). Technology enables strategies to increase informational/educational support, connection/network or social contact, family contact, emotional assistance, and patient-carers communication. These findings are backed and complemented by our survey findings, in which is evident that technology must be combined with a person-centred approach and a culture of care service that gives visibility to the needs and voices of marginalised FHBP in Australia.

Our survey indicates that prompt action is required to educate all health professionals and service providers about FHBP; educate Centrelink, NDIS, and government services about the difficulties FHBP are facing; facilitate access to community care services (e.g., NDIS, aged care packages); provide adequate Medicare rebates for home visits, and extend the existing telephone or online consults (Telehealth) for rural and remote patients to also cover FHBP in city locations (as it was done for everyone temporarily because of the first wave of COVID-19).

The academic literature, the communities we surveyed, and public opinion (e.g. news media reports), all points to the same direction: telehealth and digital technologies are effective and needed tools to combat the health marginalisation of Australia's FHBP. The task now is to educate several service providers and policymakers about the devastating consequences of maintaining a healthcare system working around the exclusory and impractical requirement of physical attendance. The negative health and psychosocial impacts of COVID-19 are highlighting the relevancy of our findings particularly concerning the groups comprising a greater proportion of FHBP, such as older people with co-morbidities and individuals living with disabilities.

\section{References}

[1] Choi, N. G., Teeters, M., Perez, L., Farar, B. and Thompson, D. (2010). Severity and correlates of depressive symptoms among recipients of Meals on Wheels: Age, gender, racial/ethnic difference. Aging \& Mental Health 14(2): 145-154.

[2] J. De Jong Gierveld, T.G. Van Tilburg, P.A. Dykstra. Loneliness and social isolation. D. Perlman, A. Vangelisti (Eds.), The Cambridge Handbook of Personal Relationships, Cambridge University Press, Cambridge (2006), pp. 485-500.

[3] Abdi, S., Spann, A., Borilovic, J., de Witte, L., \& Hawley, M. (2019). Understanding the care and support needs of older people: a scoping review and categorisation using the WHO international classification of functioning, disability and health framework (ICF). BMC geriatrics, 19(1), 195.

[4] Commonwealth of Australia | Department of Health. (2020). COVID-19 National Health Plan - Primary Care Package - MBS Telehealth Services and Increased Practice Incentive Payments. Accessed 16.04.2020. 
[5] Choi, Namkee G, Hegel, Mark T, Marti, C Nathan, Marinucci, Mary Lynn, Sirrianni, Leslie, \& Bruce, Martha L. (2014). Telehealth Problem-Solving Therapy for Depressed Low-Income Homebound Older Adults. American Journal of Geriatric Psychiatry., 22(3), 263-271.

[6] Lee, JuHee and Suh, Yujin and Kim, Yielin, Multidimensional Factors Affecting Homebound Older Adults: A Systematic Review (2020). Preprint with The Lancet. Accessed 16.04.2020.

[7] Buchanan, R. (2018). "Just Invisible" Medical Access Issues For Homebound/Bedridden Persons. Accessed on the 20/06/2019.

[8] Jang-Jaccard, J., Nepal, S., Alem, L., \& Li, J. (2014). Barriers for delivering telehealth in rural Australia: a review based on Australian trials and studies. Telemedicine and e-Health, 20(5), 496-504.

[9] Disability Insider. Telehealth cuts see services withdrawn to Australians with disabilities (2020). Coronavirus Pandemic, Disability Insider. Accessed 29/07/2020.

[10] Tsirtsakis, A. Government restricts telehealth MBS access to a patient's regular GP. NewsGP -The Royal Australian College of General Practitioners. Accessed 10/07/2020.

[11] Solomon, M. Z., Gusmano, M. K., \& Maschke, K. J. (2016). The ethical imperative and moral challenges of engaging patients and the public with evidence. Health Affairs, 35(4), 583-589.

[12] Slattery, P., Saeri, A. K., \& Bragge, P. (2020). Research co-design in health: a rapid overview of reviews. Health Research Policy and Systems, 18(1), 17.

[13] Talaga, S. R. (2013). Medicare home health benefit primer: Benefit basics and issues. Library of Congress, Congressional Research Service. March (accessed on the 20 of July 2019).

[14] Banbury A, Chamberlain D, Nancarrow S, Dart J, Gray L, Parkinson L. Can videoconferencing affect older people's engagement and perception of their social support in long-term conditions management: a social network analysis from the Telehealth Literacy Project. Health Soc Care Community. 2017;25(3):938-950. doi:10.1111/hsc.12382.

[15] Banbury A, Nancarrow S, Dart J, et al. Adding value to remote monitoring: Co-design of a health literacy intervention for older people with chronic disease delivered by telehealth - The telehealth literacy project. Patient Educ Couns. 2020;103(3):597-606. doi:10.1016/j.pec.2019.10.005.

[16] Banbury A, Nancarrow S, Dart J, et al. Adding value to remote monitoring: Co-design of a health literacy intervention for older people with chronic disease delivered by telehealth - The telehealth literacy project. Patient Educ Couns. 2020;103(3):597-606. doi:10.1016/j.pec.2019.10.005.

[17] Machesney D, Wexler SS, Chen T, Coppola JF. Gerontechnology Companion: Virtual pets for dementia patients: IEEE; 2014 Presented at Systems, Applications and Technology Conference (LISAT), 2014 IEEE Long Island; 2-2 May 2014; New York p. 1-3.

[18] Casserole Club. Available at https://www.casseroleclub.com/. Accessed on 13th July, 2020.

[19] Wearable tech lends an ear to lonely elderly. Available at: https://www.rmit.edu.au/news/allnews/2019/feb/wearable-tech-lonely-elderly. Accessed on 13th July, 2020.

[20] Seniors Enquiry Line. Available at: https://seniorsenquiryline.com.au/. Accessed on 13th July, 2020.

[21] Connect to new possibilities without leaving home. Available at: https://www.mather.com/neighborhood-programs/telephone-topics Accessed on 13th July, 2020.

[22] Mosaic Seniors. Available at: https://www.mosaicbc.org/services/settlement/seniors/ Accessed on 13th July, 2020.

[23] Be Connected Partner Map. Available at: https://beconnected.esafety.gov.au/find-local-help Accessed on 13 th July, 2020.

[24] TomNet - The older men network. Available at: Tomnet.org.au Accessed on 13th July, 2020.

[25] Yu-Chen Huang, Yeh-Liang Hsu, Social networking-based personal home telehealth system: A pilot study, Journal of Clinical Gerontology and Geriatrics, Volume 5, Issue 4, 2014, Pages 132-139, ISSN 2210-8335, https://doi.org/10.1016/j.jcgg.2014.05.004.

[26] Beyond Blue. Online social community. Available at https://www.beyondblue.org.au/get-support/onlineforums/community-rules. Accessed on 13th July, 2020.

[27] Brotherhood of St Laurence. Available at: https://www.bsl.org.au/ Accessed on 13th July, 2020.

[28] Australian Government. Be Connected. Games centre for mouse and keyboard. Available at https://beconnected.esafety.gov.au/games/games-centre Accessed on 13th July, 2020.

[29] TomNet - The older men network. Available at: Tomnet.org.au Accessed on 13th July, 2020.

[30] The University of Melbourne. Ageing and Avatars. Available at: https://socialnui.unimelb.edu.au/ research/ageing-avatars/ Accessed on 13th July, 2020.

[31] Rendever. Available at: https://rendever.com/ Accessed on 13th July, 2020.

[32] Alcohol and Drugs. Counselling online forums. Available at: https://forum.counsellingonline.org.au/ index.php Accessed on 13th July, 2020.

[33] Moyle W, Arnautovska U, Ownsworth T, Jones C. Potential of telepresence robots to enhance social connectedness in older adults with dementia: an integrative review of feasibility. Int Psychogeriatr. 2017;29(12):1951-1964. doi:10.1017/S1041610217001776. 
[34] AARP Foundation Frameworks for Isolation in adults over 50. Available at https://www.aarp.org/content/dam/aarp/aarp_foundation/2012_PDFs/AARP-Foundation-IsolationFramework-Report.pdf [Acessed on 17th April, 2020]. 